\title{
The Mediating Role of Customer Trust on Customer Loyalty
}

\section{Nha Nguyen, André Leclerc, Gaston LeBlanc}

Faculty of Business Administration, University of Moncton, Moncton, Canada.

Email: nha.nguyen@umoncton.ca, andre.leclerc@umoncton.ca, gaston.leblanc@umoncton.ca

Received November $22^{\text {nd }}, 2012$; revised December $25^{\text {th }}, 2012$; accepted January $7^{\text {th }}, 2013$

\begin{abstract}
The review of the literature reveals various relationships between the constructs of social identity, customer trust, and customer loyalty. Such results lead to questioning the nature of the conceptual structure that would include these constructs as well as their interrelationships in a structural model. From this perspective, the purpose of this study is to evaluate the mediating role of customer trust on customer loyalty in presence of corporate social identity in the context of financial institutions. Using data collected from 1296 customers-members of credit unions, the results of this study help to legitimize the idea that customer trust intervenes as a mediating variable that enhances the impact of corporate identity, corporate image and the reputation of the firm on customer loyalty. The implications of the study are discussed from both the research and managerial perspectives.
\end{abstract}

Keywords: Corporate Identity; Corporate Image; Corporate Reputation; Social Identity; Customer Trust; Customer Loyalty

\section{Introduction}

The central idea of relationship marketing consists in developing and maintaining lasting relationships with customers in order to strengthen a company's competetive edge. The customer-firm relationship can rely on various constituents, such as the product or service, employees' performance, brand name or the firm itself. Beyond these constituents, customer trust also remains an essential component in developing customer loyalty toward the firm. Several studies highlight the decisive role of customer trust in the buyer-seller relationship in the context of retailing [1-3]. In fact, the influence of customer trust on behavioral intentions is well documented in the marketing literature, notably with respect to buying intentions [3,4] and loyalty [5-11].

Moreover, other studies show the significant impact exerted by the various forms of a firm's social identity on the consumer's trust. For example, consumers have a tendency to trust a firm that has an established reputation $[12,13]$. A strong reputation can restore consumers' trust in a crisis situation [14]. In addition, corporate image is cited as a source of influence on customer trust specifically in the context of e-commerce [15].

In light of these results, in the present study we seek to combine these two types of relationship in order to evaluate the effect of social identity and customer trust as a mediating variable on customer loyalty. Three forms of social identity will be considered in the context of this study, namely corporate identity, corporate image and corporate reputation. We intend to realize this objective with the use of a causal model while keeping the focus on the customer's perspective. We are specifically interested in these concepts because they express perceptions stemming from a globalization process applied to a firm as an entity. These concepts form a chain of relationships very much worth exploring, particularly within the context of financial services. Of course, customer trust is not the only factor that explains customer loyalty. Other factors, such as service quality, service value, customer satisfaction or even price, can also modify loyalty. The proposed model, however, seeks to highlight the role that trust, as a higher order construct, has in strengthening loyalty based on customers' overall perceptions concerning the firm. On the one hand, trust plays a central role in the relationship customers have with their financial institutions. In fact, trust can have an immediate effect on the decision that customers must make, either to pursue or to end their relationship with a firm. On the other hand, various factors can also influence customer trust; but, in the present study, we emphasize exclusively the perceptions of a firm's social identity, built through corporate identity, corporate image and corporate reputation, as the antecedents of customer trust from a customer's perspective. In their search for relevant information on a given 
service, customers must deal with the absence of objective and quantifiable attributes because services are generally intangible. Such intangibility leads customers to use elements related to the firm and increases the likelihood of the globalizing of their evaluation [16-18]. In this sense, corporate identity, corporate image and corporate reputation constitute together a kind of overall assessment that stands out of all the information customers must process.

This study consists of four parts. First, an overview of the three principal forms of a firm's social identity as well as their links with customer trust and customer loyalty is investigated. Secondly, the methods used to investigate the relationships between these five constructs are presented and explained. Thirdly, the results are presented and analyzed. Finally, the managerial implications relating to the reinforcement of customer loyalty through the use of the firm's social identity, customer trust and future research are discussed.

\section{Conceptual Framework}

In the marketing literature, the concept of social identity as applied to a firm can be expressed in three principal forms: corporate identity, corporate image and corporate reputation [19-22]. The present study is based on the relationship structure illustrated in Figure 1, which incorporates these representations of social identity as antecedents of customer trust and which, in turn, affects customer loyalty.

\subsection{Social Identity}

The concept of social identity applies both to individuals as actors in a firm and to the firm itself [23]. Arising from the idea that self-identity can exist within a social context [24], the concept of social identity at the individual level has been widely studied for several decades. It was introduced into the sociological terminology at the beginning of the 1960s, and used to emphasize a person's identity within a structure of social relationships [25]. The theory of social identity was later proposed and adopted by several disciplines in the behavioral sciences in order to explain how social identity is formed [26-28]. The theory specified the quality of the relationships among the members of a group, as well as the perceptions and interpersonal relationships among the members of two or more groups [29-31]. For a person, social identity can be defined as "that part of an individual's selfconcept which derives from [her or] his knowledge of [her or] his membership in a social group (or groups) together with the value and emotional significance attached to that membership" [32].

For a few decades now, the concept of social identity has also been adapted to the context of organizations, and its applications at this level have been studied [33,34]. In fact, as is the case with an individual, an organization can also have a "social" identity built on central, lasting, and distinctive characteristics [35]. For example, the Red Cross defines itself as an organization dedicated to saving lives. A firm can develop its social identity by emphasizing that it belongs to a particular industry, highlighting its structure, and drawing attention to the fact that it is a member of an accredited group [36]. In financial services, for example, a credit union defines its social identity largely as an organization that advocates mutual aid and cooperation in order to meet the financial needs of its members, while belonging to a group of similar organizations that are all recognized in their own right in the financial sector. Although some authors suggest that an organization possesses multiple social identities [37], others consider the various forms of social identity as being social representations of the organization $[37,39]$. In the marketing literature, the use of the concept of social identity has indeed produced several forms, particularly corporate identity [21,40,41], visual identity $[19,42]$, corporate branding [20], corporate image $[22,43]$, and corporate reputation $[44,45]$. These are the notions that apply to firms as corporate entities and

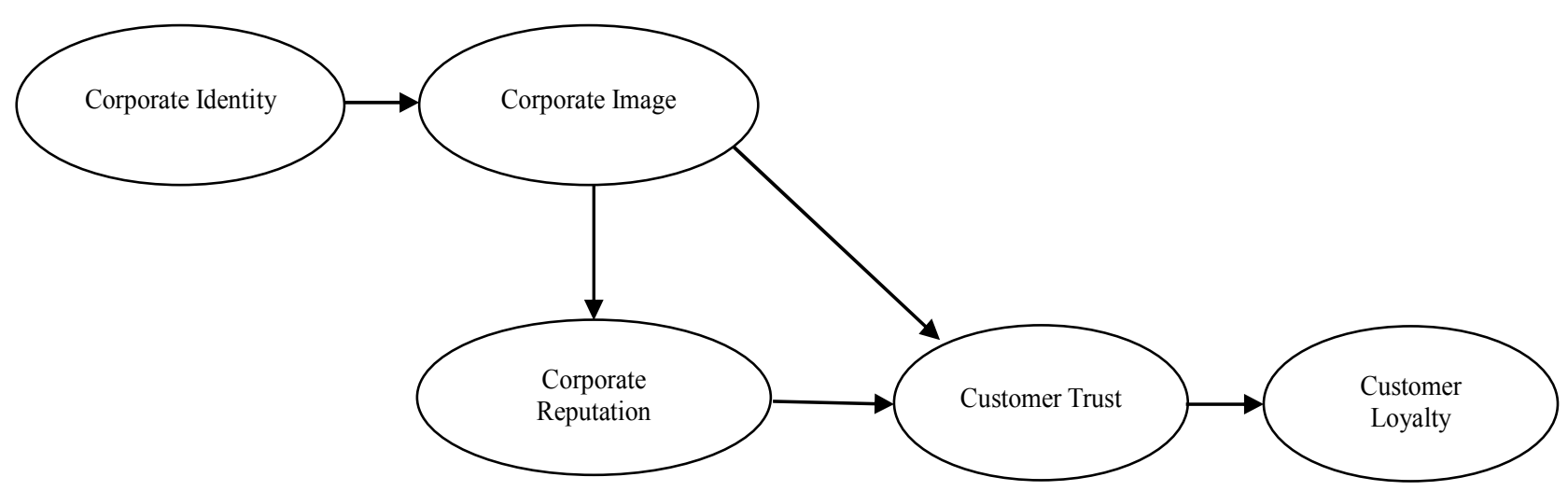

Figure 1. Conceptual framework describing the relationships among three forms of social identity, customer trust, and customer loyalty. 
that rest on corporate characteristics [46]. Within the scope of this study, we limit ourselves to three major forms of a firm's social identity, namely corporate identity, corporate image, and corporate reputation most mentioned in the marketing literature.

\subsection{Corporate Identity}

For marketing scholars who refer to what they call corporate identity, the focus is on answering the question, how is this corporate identity communicated to customers and other stakeholders? This corporate identity, however, is neither exclusively internal nor external [21]. From a marketing perspective, corporate identity is described as a holistic notion that encompasses a set of characteristics that gives a firm its uniqueness [47]. Corporate identity can be seen as an expression of the organization's history, and this identity must be managed with a well-planned process, the outcome of which would affect the corporate image $[21,46]$. While acknowledging the irrefutable relationship between corporate identity and corporate image, Abratt [19], in an attempt to clarify the issue, proposes that identity is composed of a set of physical and behavioural indicators developed and controlled by the firm, and that the corporate image is an overall impression formed in the minds of the consumer on the basis of these indicators. Since all firms project an identity to represent themselves and to stand out from all the others, it is important to note that the visual elements of corporate identity can be crucial for the consumer because of their iconic nature. In the present study, we adopt the view taken by Abratt [19] who considers corporate identity as an antecedent of corporate image.

\subsection{Corporate Image}

Corporate image is considered as a portrait that incorporates a sum of beliefs, ideas, and impressions that the customer has of a firm $[22,48,49]$. This portrait can be the result of experiences with purchasing and consuming goods or of information consumers extract from their surroundings without necessarily having had any concrete experiences with the firm itself [50]. Corporate image is composed of two realities: an "objective" reality defined by a set of business traits, such as its logo and its distinctive character, and a "subjective" reality made up of the impressions consumers draw from the main characteristics they remember [51]. It is a product of the globalization process through which the consumer seeks to position the firm in relation to its competitors. This image is global, therefore, as a consequence, yet relative, because it is constructed from comparisons with other corporate images as a means of assessment. A firm does not project a unique image. Rather, it may have various images that differ according to a specific group, such as clients, employees, and shareholders. The multiplicity of corporate images is explained by the nature of the experience and the degree of contact that target groups have with the firm, as well as by the information they receive concerning business activities [52-55]. Corporate image has both a dynamic and complex nature. Its transformation requires harmonizing the organization's activities because dissonance may destroy the impression created by the image. In addition, the creation of corporate image, which is often based on symbols, is usually a lengthy process rooted in psychological associations regarding the values or concepts being conveyed. In some circumstances, however, a corporate image can change rapidly thanks to technological advances, especially with respect to firms that realize extraordinary achievements. Since the characteristics of a firm are often reflected in its identity, it is proposed that corporate identity is an antecedent of corporate image. Therefore, we propose the following hypothesis:

Hypothesis $\mathrm{H}_{1}$ : The more positive the customer's perception is of a firm's identity, the more positive is his perception of the firm's image.

\subsection{Corporate Reputation}

The concept of corporate reputation has been studied mostly by researchers in the field of economics, organizational theory and marketing. In economics, reputation is related to a product's price and quality [56,57]. Researchers in organizational theory analyse reputation from the point of view of social identity. They describe it as an important yet intangible resource that has a very significant impact on performance, if not on the very survival of organizations [58-60]. Authors in marketing examine reputation under the guise of brand equity [61] and associate it with the firm's credibility [62]. Despite the use of a varied vocabulary and the difficulty of conceptualization, we observe that there is agreement on the essence of the notion of reputation. In fact, a firm's reputation is the direct result of its decisions and past actions. Reputation is perceived as a manifestation of the firm's history, an asset particularly when the firm's name is also its brand name. Reputation also informs the firm's various target groups of the performance of its products and services compared to those offered by its competitors [63]. Herbig and Milewicz [64] define corporate reputation as "the estimation of the consistency over time of an attribute of an entity". Consequently, a firm can have several reputations, one for each attribute according to which it devises strategies (e.g., price, product quality, innovativeness and management quality). Each firm can also have a kind of overall reputation that represents its capacity to honour the promises it makes to its customers. 
Reputation is fragile and can be ruined easily through inappropriate actions taken by a firm. Restoring a firm's reputation often requires much time and effort [64], probably because of the cumulative nature of the building process.

The review of the literature reveals very few empirical results, excepting those of a general nature, that have investigated the relationship between a firm's reputation and its image. Porter [65], for example, suggests that a good reputation enables a firm that is breaking new ground in its field of activity to build an innovative image in the opinion of its customers and competitors. For his part, Franklin [66] puts forward the idea that corporate reputation is the overall result of the corporate image building process. Nevertheless, if we rely on the general meaning accepted for each of these constructs, reputation and image are treated as external perceptions of the firm. Reputation and image both come from the same globalizing process based on information used by the consumer to assess a firm's performance. This information comes from the consumer's own experience with a firm as well as from other sources of information, such as advertisement and word of mouth. Nevertheless, because of the consumer's own experience with a firm, we think that his opinion of the reputation is generally of a more personal nature. For its part, an image can be transmitted by a third party, without a consumer needing to have entered into any prior transaction with the firm. Consumers may have a true or a false image of a firm depending on the reliability and/or origin of their information. It is possible, therefore, to note the absence of consensus in the literature regarding the direction of the relationship between image and reputation. In this study, we hypothesize that reputation is a function of image.

Hypothesis $\mathrm{H}_{2}$ : The more positive the customer's perception is of a firm's image, the more positive is his perception of the firm's reputation.

\subsection{Customer Trust}

During the past decade, the concept of trust has attracted much attention among researchers, particularly in organizational theory and marketing $[67,68]$. This concept can be analysed at different levels of social interaction: interpersonal, intergroup, and inter-organizational. In marketing, the central role of trust is recognized in developing and maintaining relationships between those who take part in an exchange process $[69,70]$, especially within a buyer-seller relationship with a view to acquiring goods or services [12,71].

Trust is defined as the level of reliability ensured by one party to another within a given exchange relationship [72]. In a marketing context, trust is usually linked to consumer expectations concerning the firm's capacity to assume its obligations and keep its promises [12,73-75]. These expectations are based on the firm's competence, honesty, and benevolence [73,76,77]. Competence is expertise; and, for customers, it reflects the firm's capacity to carry out transactions and to live up to their expectations [78]. Honesty is associated with fulfilling promises made by the firm, and benevolence represents the firm's willingness to take into consideration consumer interests when making decisions and when planning for engagement in customer relationship activities [70,7981]. The role of trust in forming behavioural intentions is well defined in the literature. For example, trust enables a firm to develop and to maintain customer loyalty $[5,9$, 10]. Consumers who trust a firm expect promises to be respected as advertised. They also expect the firm to act based upon their interests.

Certain studies suggest that trust is a mediating variable within a model that encompasses various components of the consumer-brand relationship [82]; or, it is the result of a chain of effects that includes the different forms of assessment carried out by consumers and their commitment [83], or even their loyalty [8]. In this study, we present trust as a mediating variable between the consumer's perceptions of the firm in its various forms of social identity and his loyalty to the firm. Two reasons justify our choice. Firstly, previous research underlines the closely knit relationship between some forms of social identity and trust. For consumers, for example, a firm's already established reputation represents an indicator of their trust in this firm $[12,13]$; or it can restore consumers' trust in a crisis situation [14]. In addition, corporate image is said to influence trust in different contexts, notably in financial services [84] and e-commerce [15]. Secondly, social identity is an important construct that applies to a firm as a corporate-level concept that rests on a series of decisions and actions taken by the firm and that is often at the origin of customer trust $[3,4,85]$. To build or enhance customer trust, the research to date suggests that the firm's strategy be based, among others, on nurturing a positive image $[15,84]$ and a solid reputation $[77,86,87]$. We offer, therefore, the following hypotheses concerning the relationship between image and reputation as antecedents of customer trust.

Hypothesis $\mathrm{H}_{3}$ : The more positive the customer's perception is of a firm's image, the greater is his trust in the firm.

Hypothesis $\mathrm{H}_{4}$ : The more positive the customer's perception is of a firm's reputation, the greater is his trust in the firm.

\subsection{Customer Loyalty}

Although the typically loyal customer can be described 
as the one who purchases repeatedly the same brand, brand loyalty cannot be measured solely by this buying behaviour since the decision to buy a brand may be influenced by other variables such as social norms [88] and situational factors [89]. Similarly, a psychological dimension expressed in the form of an attitude or preference must also be included within the notion of loyalty [90-92]. In fact, this "composite" approach to understanding loyalty is based on the hypothesis that consumers' decisions to buy are guided by a conscientious assessment of available brands. However, the literature acknowledges that in many circumstances the consumer does not always go through an assessment process before buying a product. The risk exists, therefore, that genuine loyalty will not be recognized by the "composite" approach, even if the outcome bypasses a consumer's psychological commitment to the brand. To complete the "composite" approach, which remains the most widely accepted approach in the literature, one must analyse the buying behaviour in contexts in which consumers are exposed to pressure aimed at modifying their behaviour [93]. Thus, brand loyalty is genuinely present when consumers resist the temptation to change brands [94,95]. For other authors, loyalty can be defined in two ways: as an attitude and as a behaviour [96]. As an attitude, loyalty expresses a consumer's desire to establish a relationship with a firm. The problem, then, is to verify if this intention will translate into actions. From a behavioural standpoint, loyalty is defined as repeated support given to a single firm. This behaviour can be influenced by habits, by other people, or by a random choice. In this way, four stages are necessary in order to develop customer loyalty: cognitive, affective, intentional, and behavioural [97]. Whether it is perceived as an attitude or type of behaviour, loyalty is one of many elements that determine consumers' decisions to buy.

Identifying the elements that influence customer loyalty represents, therefore, a major research theme for those who wish to understand the performance and sustainability of firms. Several hypotheses have been tested, notably the links between consumer trust, perceived value, and customer loyalty [6]; the relationships between perceived quality, satisfaction, and image, and buying intentions, as surrogate indicators of loyalty [98, 99]; and even the relationships between reputation, quality, value, and loyalty with respect to online services [44]. Other studies conducted in the B2B context show that loyalty depends in particular on firms' trust in their suppliers, on the relational culture established by the latter, on the absence of conflict between two parties, and on a competitive level [100]. In most of the studies perused, the direct relationship between customer trust and customer loyalty is, of course, a major point of interest; but it is often part of a causal structure in the presence of other constructs, such as image, reputation, quality, value, satisfaction, and even commitment [6,8,101-103]. Based on the foregoing review of the literature, the following hypothesis is stated:

Hypothesis $\mathrm{H}_{5}$ : The greater the customer's trust is in a firm, the greater is his loyalty toward the firm.

As stated in the introduction, the focus of this study is primarily on the causal structure that encompasses various forms of corporate social identity and customer trust as sources of influence on customer loyalty in a financial service setting.

\section{Method}

\subsection{Sampling}

The survey was carried out among members of twentyone (21) credit unions serving mostly the French population in the province of New Brunswick in Canada. Three hundred members were randomly selected from each credit union. To ensure the participants' confidentiality, each credit union was responsible for mailing the questionnaires and returning envelopes. The survey was conducted over a period of three weeks without a follow-up letter. A total of 1296 completed questionnaires were returned within this time frame corresponding to a $20.6 \%$ response rate. Table 1 shows some of the main characteristics of the respondents.

In light of the results presented in Table 1, it is possible to note that $55.8 \%$ of respondents were women. With regard to age groups, $75 \%$ were aged 45 and over. Respondents had been members of a credit union for 10 studies $(56.1 \%)$, went to their credit union at least three times per month (61\%), and earned less than $\$ 45,000$ yearly $(61.9 \%)$.

\subsection{Measurement}

The review of the literature reveals that few scales have been developed for the measurement of the constructs used in the present study, as well as the absence of a consensus on the reliability of these scales. For example, a multidimensional scale for measuring brand trust was developed for cosmetic products [83]. This scale, however, which applies only to a brand, proved to be too specific for use in this study because it does not capture trust in the context of an intangible service. In the case of corporate image, despite the fact that numerous authors have stressed the importance of developing a measurement scale for service firms, to our knowledge no largely accepted scales exist in the field. Recently, a multi-item scale was proposed to assess the corporate image of internet banking services [104]. This scale also is too specific to be used in this study. With respect to corporate reputation, a multidimensional scale was developed 
Table 1. Sample profile.

\begin{tabular}{|c|c|}
\hline Socio-demographic Characteristics & Percentage $(\%)$ \\
\hline \multicolumn{2}{|l|}{ Gender } \\
\hline Female & 55.8 \\
\hline Male & 44.2 \\
\hline \multicolumn{2}{|l|}{ Age } \\
\hline $18-24$ & 3.4 \\
\hline $25-44$ & 23.6 \\
\hline $45-64$ & 57.3 \\
\hline $65+$ & 15.7 \\
\hline \multicolumn{2}{|l|}{ Duration of Membership } \\
\hline Less than 3 years & 2.3 \\
\hline 7 - 9 years & 2.4 \\
\hline $4-6$ years & 3.3 \\
\hline $10+$ years & 92 \\
\hline \multicolumn{2}{|l|}{ Level of Schooling } \\
\hline Secondary school or less & 43.8 \\
\hline College & 25 \\
\hline University & 31.2 \\
\hline \multicolumn{2}{|l|}{ Frequency of Visits } \\
\hline Zero per month & 10.5 \\
\hline Once or twice per month & 28.5 \\
\hline At least three times per month & 61 \\
\hline \multicolumn{2}{|l|}{ Income } \\
\hline Less than $\$ 30,000$ & 37.3 \\
\hline$\$ 30,000-\$ 44,999$ & 24.6 \\
\hline$\$ 45,000-\$ 59,999$ & 15.6 \\
\hline$\$ 60,000-\$ 99,999$ & 17.4 \\
\hline$\$ 100,000$ or more & 5.1 \\
\hline
\end{tabular}

for a number of firms selected among several industries [105], but its scope was too broad to be used in the financial services sector. More recently, another multidimensional scale for measuring corporate reputation was proposed for service firms, including financial services [106]. Yet, this scale fails to consider important dimensions specific to cooperative organizations, such as the participation of customers-members in managing their financial organisation. In this context, in order to quantify the five constructs forming the causal model presented in Figure 1, we used direct measures based on global evaluations with respect to the generally accepted meaning of these constructs presented in the literature. This approach also recognizes the advantage of using this type of measure through the use of multiple indicators [107]. From this perspective, the purpose of the present study is not to develop multidimensional scales for these constructs but rather to verify empirically the proposed causal structure.

Three items for the measurement of corporate identity were used. The first item was related to the logo of the firm and the two others reflected the distinctive character of the provider of financial services more precisely the "mutual aid" nature of the credit union and the credit union's perceived differences from a bank. Three items were also selected to describe corporate image, that is, the firm's name, the customer's impression of the firm, and an assessment of the firm's image compared with that of the competitors. For corporate reputation, three items were chosen to capture the construct: the firm's capacity to keep promises, an evaluation of the credit union's reputation compared to competitors, and the perceived fairness of the firm's decisions and actions. Concerning customer trust, four items were selected to represent this construct's components based on the literature: one item for competence, one item for integrity, and two items for benevolence (altruism and reciprocity). Finally, three items pertain to customer loyalty as proposed by Zeithaml, Berry, and Parasuraman [108]: the customer's intention to consider the firm as a first choice for this type of service, the intention of continuing to do business with the firm, and the intention to recommend the firm to others. All of the measures were presented in a statement on a bipolar seven-point Likert type agreement scale with anchors of strongly disagree (1) and strongly agree (7). The items used in this study appear the Appendix. Reliability and validity results for the measures are discussed in the next section.

\section{Results}

To verify the hypotheses listed above, the causal model was tested using the maximum-likelihood estimation procedure of Analysis of Moment Structures (AMOS) version 18.0. The results of the overall model were considered acceptable in accordance with the model's main statistics, except for the value $\chi^{2} / \mathrm{n}=3.75$, which was slightly above the norm (i.e., 3.00), but statistically significant at $\mathrm{p}=0.000$ [109]. Indicators, such as the "Normed Fit Index" (NFI = 0.930), the "Incremental Fit Index" (IFI = 0.935), and the "Comparative Fit Index" $(\mathrm{CFI}=0.935)$, were also acceptable. Furthermore, the value of the indicator "root mean square error of approximation" (RMSEA) was equal to 0.076 , which is below the limit of acceptability of 0.08 [109]. 


\subsection{Reliability}

We evaluated the reliability of the five constructs using a composite reliability index. The reliability values (Jöreskog's rhô, $\rho$ c) were $0.71,0.87,0.87,0.91$, and 0.89 , respectively for corporate identity, corporate image, corporate reputation, customer trust, and customer loyalty. Excluding corporate identity, for which the Jöreskog's rhô value is below 0.8 , we note that the measures of the other constructs were indeed reliable.

\subsection{Convergent Validity}

We conducted the assessment of the convergent validity according to two criteria: the factor loadings of the indicators and the average variance extracted (AVE) for each factor [110]. As shown in Table 2, the factor loadings vary between 0.539 and 0.891 , and are all significant statistically $(p=0.000)$. The AVE values for each factor were 0.46 for corporate identity, 0.69 for corporate image, 0.70 for corporate reputation, 0.73 for customer trust and 0.72 for customer loyalty. Excluding the AVE value for corporate identity being slightly below 0.50 , the overall results still show evidence of convergent validity of the measures used for these constructs.

\subsection{Discriminant Validity}

We verified the discriminant validity of the latent variables according to the procedure proposed by [110] by comparing the AVE values of each pair of variables to their squared correlation coefficient. Excluding the case of the variable identity ( $\mathrm{AVE}=0.46$ ), the AVE values of the other variables $(0.69,0.70,0.73$, and 0.72 , ) were above the squared correlation coefficient of each pair of variables $(0.65$ for identity-image, 0.67 for image-reputation, 0.22 for image-trust, 0.28 for reputation-trust, and 0.65 for trust-loyalty). In light of these results, we argue

Table 2. Summary results of construct measures.

\begin{tabular}{|c|c|c|c|c|}
\hline Constructs & Factor loadings & $\mathrm{t}^{*}$ & Jöreskog's $\rho$ & AVE \\
\hline Corporate Identity & & & 0.71 & 0.46 \\
\hline Cooperative form of organization & 0.772 & Fixed & & \\
\hline A credit union is different from a bank & 0.539 & 17.928 & & \\
\hline My credit union's logo & 0.677 & 23.555 & & \\
\hline Corporate Image & & & 0.87 & 0.69 \\
\hline I always have a good impression of my credit union & 0.808 & Fixed & & \\
\hline My credit union projects a better image than its competitors & 0.839 & 35.292 & & \\
\hline The name of the credit union comes to my mind first & 0.836 & 35.054 & & \\
\hline Corporate Reputation & & & 0.87 & 0.7 \\
\hline My credit union always keeps its promises & 0.847 & 38.546 & & \\
\hline My credit union has a better reputation that its competitors & 0.811 & 35.094 & & \\
\hline My credit union is fair in the decisions it makes and actions it takes & 0.839 & Fixed & & \\
\hline Customer Trust & & & 0.91 & 0.73 \\
\hline The integrity of my credit union & 0.817 & 40.368 & & \\
\hline Expertise in financial services at my credit union & 0.847 & 43.346 & & \\
\hline My credit union is always concerned with the well- being of its members & 0.891 & Fixed & & \\
\hline The well-being of the members is more important to my credit union than its financial performance & 0.819 & 40.648 & & \\
\hline Customer Loyalty & & & 0.89 & 0.72 \\
\hline My credit union remains my first choice & 0.879 & Fixed & & \\
\hline I still do business with my credit union & 0.86 & 42.262 & & \\
\hline I recommend the credit union to people in my surrounding & 0.795 & 35.53 & & \\
\hline
\end{tabular}

*All of the Student $t$ were statistically significant $(p=0.000)$. 
that it is possible to conclude that the five constructs were distinct.

\subsection{Verification of Research Hypothesis}

The results of the assessment presented in Table 3 reveal that all of the hypothesized relationships described in Figure 1 were confirmed.

Hypothesis $\mathbf{H}_{\mathbf{1}}$ : Corporate identity and corporate image

The effect of corporate identity on corporate image was confirmed with $\beta=0.81(\mathrm{p}=0.000)$. This result is consistent with the idea that corporate identity is a source of information used in the process of image building [19, 42]. Taking into account the absence of consensus about this relationship in the literature, this result helps clarify the distinction between these two constructs. While corporate identity, which is essentially composed of physical and behavioral indicators, is used to specify a firm as a distinct entity, usually in relation to others in the same industry, corporate image represents its portrait, which is the overall impression left on a customer's mind. Corporate identity is, therefore, an identification tool, whereas corporate image is, in a sense, an overall response by consumers to everything that the firm represents.

Hypothesis $\mathbf{H}_{2}$ : Corporate image and corporate reputation

The influence of corporate image on corporative reputation, as stated in hypothesis $\mathrm{H}_{2}$, was confirmed with $\beta=$ $0.82(\mathrm{p}=0.000)$. This relationship, verified in our study, corresponds to a proposition raised in the literature [66], to the effect that corporate reputation is the overall and end result of the corporate image-building process. In our opinion, corporate image and corporate reputation come from the same globalizing process based on information used by the consumer to assess the firm's performance. However, corporate image is an overall portrait formed by the consumer without necessarily having had previous experiences with the firm, whereas corporate reputation represents a more personal evaluation carried out by consumers, informed by their experiences with the firm. According to this distinction, the result from the second hypothesis suggests that corporate image, as an evaluation of the firm, can exist in the mind of customers before they even catch a hint of the firm's reputation.

Hypothesis $\mathrm{H}_{3}$ : Corporate image and customer trust

The effect of corporate image on customer trust, as identified in this study with $\beta=0.53$ ( $\mathrm{p}=0.000$ ), confirms the results of several earlier studies on the nature of the relationship between these two constructs [15,84, 111]. There is a consensus in the literature regarding the existence of a relationship between image and trust, but the direction of this relationship is still uncertain. For example, some authors stress that trust coupled with credibility is a key element to use in the corporate image building process [112]; whereas others claim that, in a long-term relationship, a positive image serves the purpose of maintaining consumer trust [94]. In this study, image is considered a source of trust because most (92\%) customer-members of the credit unions who participated in the survey have been with their financial institution for a long time, that is, for over 10 years. In this way, corporate image can be viewed as an important publicity tool that is likely to strengthen the customer's trust [113].

Hypothesis $\mathbf{H}_{4}$ : Corporate reputation and customer trust

The hypothesis, which puts forward the impact of corporate reputation on customer trust, was also confirmed with $\beta=0.47(\mathrm{p}=0.000)$, in accordance with other studies $[45,86]$. This relationship is in harmony with the preceding argument advanced about the idea that image and reputation are derived from the same globalizing process.

Hypothesis $\mathbf{H}_{5}$ : Customer trust and customer loyalty

The last hypothesis on the role of customer trust in reinforcing customer loyalty was accepted with $\beta=0.81$ ( $\mathrm{p}$ $=0.000)$. This confirms the results obtained in other studies regarding the direct relationship between trust and loyalty $[6,8,101-103]$. This hypothesis, verified in

Table 3. Regression coefficients and statistics for the causal model.

\begin{tabular}{|c|c|c|c|}
\hline Path & Standardized regression coefficients $\beta$ & $\mathrm{t}$ & $\mathrm{p}$ \\
\hline Corporate Identity $\rightarrow$ Corporate Image & 0.81 & 21.84 & 0.000 \\
\hline Corporate Image $\rightarrow$ Corporate Reputation & 0.82 & 27.33 & 0.000 \\
\hline Corporate Image $\rightarrow$ Customer Trust & 0.53 & 4.82 & 0.000 \\
\hline Corporate Reputation $\rightarrow$ Customer Trust & 0.47 & 4.08 & 0.000 \\
\hline Customer Trust $\rightarrow$ Customer Loyalty & 0.81 & 31.15 & 0.000 \\
\hline \multicolumn{4}{|c|}{$\chi_{99}^{2}=372.053(\mathrm{p}=0.000) ; \mathrm{NFI}=0.930 ; \mathrm{IFI}=0.935 ; \mathrm{CFI}=0.935 ; \mathrm{RMSEA}=0.076$} \\
\hline
\end{tabular}


our study, is in conformity with the quasi-consensus observed in the literature. Yet, we argue in favor of a contribution to the body of knowledge when we consider the mediating role of customer trust between the perceptions of various forms of social identity and customer loyalty.

\section{Discussion}

The results of this study demonstrate the mediating role of customer trust between social identity (in its three forms: corporate identity, corporate image, and corporate reputation) and customer loyalty. These results suggest to managers of financial institutions two avenues worth exploring to develop and reinforce customer loyalty.

Firstly, a financial institution must be able to adequately manage all three forms of social identity in order to build or reinforce customer trust. For example, corporate identity must rely on physical elements likely to create favourable and lasting impressions in customers' minds $[19,21,46]$. In this way, corporate identity plays a precursor role in the positioning of the organization and exerts a positive influence on customers' perceptions of the firm's image in a competitive setting. To improve its image and enhance its reputation, a financial institution must count on elements that will ensure the success of its service delivery system. One of these elements must be contact personnel. Contact personnel are composed of all employees located at the organization's frontline and are those who have direct contact with customers. For customers, contact personnel represent a prominent dimension of a service organization's image because they are the first point of meeting in the service encounter. Moreover, as the firm's privileged representatives, their role continues through the service cycle. These employees not only carry out their functions in sales and marketing, but they are also the loyal embodiment of the values conveyed by the organization. Therefore, taking care of the image projected by contact personnel contributes to the improvement of the organization's image. In a similar way, the performance of contact personnel helps to define the organization's reputation and attract new customers. Performance depends greatly on these employees' ability to provide and guarantee the service that will meet customers' needs. This ability rests, in turn, on two major characteristics of the service employees: namely, their competence and benevolence. Competence is the capacity of employees to produce transactions requested by the customer and to perform in such way as to meet his expectations [114], while benevolence is synonymous with the willingness to take into consideration the customer's interests and to act with sensitivity to his needs [80]. Thus, it is crucial for a financial institution to include these two characteristics in the planning of its human resources. Competence must be combined with be- nevolence in order to maximize employee performance and, as a result, reinforce the organization's reputation and customer trust.

Secondly, to build customer loyalty and sustain it, relationship marketing can play a key role to influence positively customers' perceptions of the organization and to enhance customer trust. Loyalty is not determined exclusively by the intrinsic characteristics of service offer. It can also depend on external traditional activities, such as advertising and public relations, well known to those in charge of marketing. So, the choice of elements for positioning and communication strategies must reflect the reality and ability of the organization to keep the promises of quality and benefit made to its customers in order to bridge the gap between action and rhetoric. It is important to note that the gap between action and rhetoric can produce a vague and contradictory image, and it can develop a bad reputation and a loss of trust. Because of the long process necessary in shaping corporate social identity and customer trust, a firm's actions must be systematically organized in the form of scenarios in such way as to avoid bad actions thereby provoking the destruction of social identity and trust. Preventive measures must be set up to avoid this kind of negative impact and must involve all of the employees in the organization, especially contact personnel, who are the frontline and who interact with customers.

\section{Conclusion}

The purpose of this study was to verify empirically a causal model in a financial service setting that links the three forms of a firm's social identity, namely corporate identity, corporate image, and corporate reputation, to customer trust as factors leading to customer loyalty reinforcement. The results obtained have enabled us to confirm the significant impact of the chain of effect identity-image-reputation on customer trust, which in turn affects customer loyalty. However, it is important to underline several limitations of the present study. Firstly, the causal structure is not complete because it contains only corporate-level concepts as explanatory factors. Secondly, our results do not allow for the generalization to all types of services because of the great variety across service sectors, especially since the data were collected from a convenient sample of consumers-members in a credit union setting. Thirdly, the efficacy of the direct measures used to assess the five constructs in the model must be considered [115]. The selection of these measures was based on the meaning of each of these constructs in the absence of appropriate measurement scales. With regard to future research, it would be useful to proceed with studies on redundancy (or non-redundancy) of the diverse forms of social identity in order to clearly 
establish the distinction between them. Finally, it would be interesting to develop measurement scales for these constructs and to include them with other variables, such as the quality and the perceived value of the service provided in a more complete causal structure with which to explain consumer loyalty.

\section{REFERENCES}

[1] S. Ganesan, "Determinant of Long-Term Orientation in Buyer-Seller Relationships," Journal of Marketing, Vol. 58, No. 2, 1994, pp. 1-19. doi:10.2307/1252265

[2] L. H. Too, A. L. Souchon and P. C. Thirkell, "Relationship Marketing Customer Loyalty in a Retail Setting: A Dyadic Exploration," Journal of Marketing Management, Vol. 17, No. 3-4, 2001, pp. 287-319.

[3] J. J. Zboja and C. M. Voorhees, "The Impact of Brand Trust and Satisfaction on Retailer Purchase Intentions," Journal of Services Marketing, Vol. 20, No. 5, 2006, pp. 381-390. doi:10.1108/08876040610691275

[4] S. T. K. Luk and L. S. C. Yip, "The Moderator Effect of Monetary Sales Promotion on the Relationship between Brand Trust and Purchase Behaviour," Brand Management, Vol. 15, No. 6, 2008, pp. 452-464.

[5] S. Chow and R. Holden, "Toward an Understanding of Loyalty: The Moderating Role of Trust," Journal of Managerial Issues, Vol. 9, No. 3, 1997, pp. 275-298.

[6] K.-M. Chu, "The Construction Model of Customer Trust, Perceived Value and Customer Loyalty," Journal of American Academy of Business, Vol. 14, No. 2, 2009, pp. 98-103.

[7] E. Delgado-Ballester and J. L. Munuera-Aleman, "Brand Trust in the Context of Consumer Loyalty," European Journal of Marketing, Vol. 35, No. 11/12, 2001, pp. 12381258. doi:10.1108/EUM0000000006475

[8] P. Guenzi, M. D. Johnson and S. Castaldo, "A Comprehensive Model of Customer Trust in Two Retail Stores," Journal of Service Management, Vol. 20, No. 3, 2009, pp. 290-316. doi:10.1108/09564230910964408

[9] T. Harrison, "Why Trust Is Important in Customer Relationships and How to Achieve It," Journal of Financial Services Marketing, Vol. 7, No. 3, 2003, pp. 206-209. doi:10.1057/palgrave.fsm.4770084

[10] D. Sirdeshmukh, J. Sing and B. Sabol, "Consumer Trust, Value, and Loyalty in Relational Exchanges," Journal of Marketing, Vol. 66, No. 1, 2002, pp. 15-37. doi:10.1509/jmkg.66.1.15.18449

[11] P.-C. Sun and C.-M. Lin, "Building Customer Trust and Loyalty: An Empirical Study in a Retailing Context," The Services Industries Journal, Vol. 30, No. 9, 2010, pp. 1439-1449. doi:10.1080/02642060802621478

[12] C. Moorman, G. Zaltman and R. Deshpande, "Relationships between Providers and Users of Market Research: The Dynamics of Trust Within and between Organizations," Journal of Marketing Research, Vol. 29, No. 3, 1992, pp. 314-328. doi:10.2307/3172742

[13] P. Mitchell, J. Roast and J. Lynch, "Exploring the Foun- dations of Trust," Journal of Marketing Management, Vol. 14, No. 1-3, 1998, pp. 150-172.

[14] S. A. Greyser, "Corporate Brand Reputation and Brand Crisis Management," Management Decision, Vol. 47, No. 4, 2009, pp. 590-605. doi:10.1108/00251740910959431

[15] M. Zhou and D. Tian, “An Integrated Model of Influential Antecedents of Online Shopping Initial Trust: Empirical Evidence in a Low-Trust Environment," Journal of International Consumer Marketing, Vol. 22, No. 2, 2010, pp. 147-162. doi:10.1080/08961530903476212

[16] P. Eiglier and É. Langeard, (1987). "Servuction, le Marketing des Services," McGraw-Hill, Paris.

[17] C. Gronroos, "Relationship Marketing: The Strategy Continuum," Journal of the Academy of Marketing Science, Vol. 23, No. 4, 1995, pp. 252-254.

[18] C. Lovelock and J. Wirtz, "Principles of Service Marketing and Management," 6th Edition, Prentice-Hall, Upper Saddle River, 2006.

[19] R. Abratt, "A new Approach to the Corporate Image Management Process," Journal of Marketing Management, Vol. 5, No. 1, 1989, pp. 63-76. doi:10.1080/0267257X.1989.9964088

[20] J. M. T. Balmer and S. A. Greyser, "Corporate Marketing, Integrating Corporate Identity, Corporate Branding, Corporate Communications, Corporate Image and Corporate Reputation," European Journal of Marketing, Vol. 40, No. 7/8, 2006, pp. 730-741. doi:10.1108/03090560610669964

[21] A. Blombäck and O. Brunninge, "Corporate Identity Manifested through Historical References," Corporate Communications: An International Journal, Vol. 14, No. 4, 2009, pp. 404-419. doi:10.1108/13563280910998754

[22] P. Kotler, D. H. Haider and I. Rein, "Marketing Places," The Free Press, New York, 1993.

[23] H. Rao, G. Davis and A. Ward, "Embeddedness, Social Identity and Mobility: Why Firms Leave the NASDAQ and Join the New York Stock Exchange," Administrative Science Quarterly, Vol. 45, No. 2, 2000, pp. 268-292. doi: $10.2307 / 2667072$

[24] G. H. Mead, "Mind, Self, and Society," University of Chicago Press, Chicago, 1934.

[25] G. P. Stone, “Appearance and the Self," In: A. M. Rose, Ed., Human Behavior and Social Processes, Houghton Miffin, Boston, 1962, pp. 86-118,

[26] J. E. Coté and C. Levine, "Identity Formation, Agency, and Culture," Lawrence Erlbaum Associates, Mahwah, 2002.

[27] H. Tajfel and J. C. Turner, "An Integrative Theory of Intergroup Conflict," In: G. W. Austin and S. Worchel Eds., Psychology of Intergroup Relations, Brooks/Cole, Monterey, 1979, pp. 7-24.

[28] H. Tajfel and J. C. Turner, "The Social Identity Theory of Intergroup Behavior," In: S. Worchel and G. W. Austin, Eds., Psychology of Intergroup Relations, Nelson-Hall, Chicago, 1986, pp. 7-24.

[29] W. Brekhus, "Trends in the Qualitative Study of Social Identities," Social Compass, Vol. 2, No. 3, 2008, pp. 1059-1078. doi:10.1111/j.1751-9020.2008.00107.x 
[30] J. E. Coté, "Identity Studies: How Close Are We to Developing a Social Science of Identity?-An Appraisal of the Field," Identity: An International Journal of Theory and Research, Vol. 6, No. 1, 2006, pp. 3-25. doi:10.1207/s1532706xid0601 2

[31] M. J. Hornsey, "Social Identity Theory and Self-Categorization Theory: A Historical Review," Social and Personality Psychology Compass, Vol. 2, No. 1, 2008, pp. 204-222. doi.org/10.1111/j.1751-9004.2007.00066.x

[32] H. Tajfel, "Human Groups and Social Categories," Cambridge University Press, Cambridge, 1981.

[33] B. Ashforth, "Role Transitions in Organizational Life: An Identity-Based Perspective," Erlbaum, Hillsdale, 1999.

[34] J. E. Dutton and M. Dukerich, "Keeping an Eye on the Mirror: Image, and Identity in Organizational Adaptation," Academy of Management Journal, Vol. 34, No. 3, 1991, pp. 517-554. doi:10.2307/256405

[35] S. Albert and D. A. Whetten, (1985). "Organizational Identity," In: B. M. Staw and L. L. Cummings, Eds., Research in Organizational Behavior, JAI Press, Greenwich, pp. 263-295.

[36] D. Gioia, "From Individual to Organizational Identity," In: D. Whetten and P. Godfrey, Eds., Identity in Organizations, Sage, Thousand Oaks, 1998, pp. 17-32.

[37] J. M. T. Balmer and S. A. Greyser, "Managing the Multiple Identities of the Corporation," California Management Review, Vol. 44, No. 3, 2002, pp. 72-86. doi: $10.2307 / 41166133$

[38] S. Moscovici, "Notes toward a Description of Social Representations," European Journal of Social Psychology, Vol. 18, No. 3, 1988, pp. 211-250. doi:10.1002/ejsp. 2420180303

[39] M. Schuler, "Management of the Organizational Image: A Method for Organizational Image Configuration," Corporate Reputation Review, Vol. 7, No. 1, 2004, pp. 37-53. doi:10.1057/palgrave.crr.1540210

[40] T. Garry, A. J. Broderick and K. Lahiffe, "Tribal Motivation in Sponsorship and Its Influence on Sponsor Relationship Development and Corporate Identity," Journal of Marketing Management, Vol. 24, No. 9, 2008, pp. 959972. doi:10.1362/026725708X381993

[41] J. M. Handelman, "Corporate Identity and the Social Constituent," Journal of the Academy of Marketing Science, Vol. 34, No. 2, 2006, pp. 107-114. doi:10.1177/0092070305284970

[42] W. Olins, "Corporate Identity-Making Business Strategy Visible through Design," Thames and Hudson, London, 1989.

[43] H. Barich and P. Kotler, "A Framework for Marketing Image Management," Sloan Management Review, Vol. 32, No. 2, 1991, pp. 94-104.

[44] A. Caruana and M. Ewing, "How Corporate Reputation, Quality, and Value Influence Online Loyalty," Journal of Business Research, Vol. 63, No. 9-10, 2010, pp. 11031119. doi:10.1016/j.jbusres.2009.04.030

[45] H. T. Keh and Y. Xie, "Corporate Reputation and Customer Behavioural Intentions: The Roles of Trust, Identification and Commitment," Industrial Marketing Man- agement, Vol. 37, No. 7, 2009, pp. 732-744. doi:10.1016/j.indmarman.2008.02.005

[46] J. M. T. Balmer, "Identity Based Views of the Corporation," European Journal of Marketing, Vol. 42, No. 9/10, 2008, pp. 879-906. doi:10.1108/03090560810891055

[47] J. M. T. Balmer and E. R. Gray, "Corporate Brands: What Are They? What of Them?" European Journal of Marketing, Vol. 37, No. 7-8, 2003, pp. 972-997. doi:10.1108/03090560310477627

[48] G. R. Dowling, "Corporate Reputations: Should You Compete on Yours," California Management Review, Vol. 46, No. 3, 2004, pp. 19-36. doi:10.2307/41166219

[49] N. Pope, K. E. Voges and M. Brown, "Winning Ways: Immediate and Long-Term Effects of Sponsorship on Perceptions of Brand Quality and Corporate Image," Journal of Advertising, Vol. 38, No. 2, 2009, pp. 5-20. doi:10.2753/JOA0091-3367380201

[50] T. W. Andreassen and B. Lindestad, "The Effect of Corporate Image in the Formation of Customer Loyalty," Journal of Service Research, Vol. 1, No. 1, 1998, pp. 8292. doi:10.1177/109467059800100107

[51] D. Mazursky and J. Jacoby, Exploring the development of store images. Journal of Retailing, Vol. 62, No. 2, 1986, pp. 145-165.

[52] G. R. Dowling, "Measuring Corporate Images: A Review of Alternative Approaches," Journal of Business Research, Vol. 17, No. 1, 1988, pp. 27-34. doi:10.1016/0148-2963(88)90019-7

[53] M. M. Parent and P. O. Foreman, "Organizational Image and Identity Management in Large-Scale Sporting Events," Journal of Sport Management, Vol. 21, No. 1, 2007, pp. 2-12.

[54] K. Price and D. A. Gioia, "The Self-Monitoring Organization: Minimizing Discrepancies among Differing Images of Organizational Identity," Corporate Reputation Review, 11, No. 4, 2008, pp. 208-221. doi:10.1057/crr.2008.17

[55] K. Price, D. A. Gioia and K. G. Corley, "Reconciling Scattered Images: Managing Disparate Organizational Expressions and Impressions," Journal of Management Inquiry, Vol. 17, No. 3, 2008, pp. 173-195. doi: $10.1177 / 1056492608314991$

[56] C. Shapiro, "Premiums for High Quality Products as Returns to Reputations," Quarterly Journal of Economics, Vol. 98, No. 4, 1983, pp. 659-679. doi:10.2307/1881782

[57] H. W. Wilson, "Reputations in Games and Markets," In: A. E. Roth, Eds., Game-Theoretic Models of Bargaining, Cambridge University Press, New York, 1985, pp. 65-84.

[58] C. Fombrun and M. Shanley, "What's in a Name? Reputation Building and Corporate Strategy," Academy of Management Journal, Vol. 33, No. 2, 1990, pp. 233-248. doi: $10.2307 / 256324$

[59] R. Hall, "A Framework Linking Intangible Resources and Capabilities to Sustainable Advantage," Strategic Management Journal, Vol. 14, No. 8, 1993, pp. 607-618. doi:10.1002/smj.4250140804

[60] H. Rao, "The Social Construction of Reputation: Certifi- 
cation Contests, Legitimation, and the Survival of Organizations in the American Automobile Industry: 18951912," Strategic Management Journal, Vol. 15, Suppl. 1, 1994, pp. 29-44. doi:10.1002/smj.4250150904

[61] D. A. Aaker, "Managing Brand Equity," The Free Press, New York, 1996.

[62] P. Herbig, J. Milewicz and J. Golden, "A Model of Reputation Building and Destruction," Journal of Business Research, Vol. 31, No. 2-3, 1994, pp. 23-31. doi:10.1016/0148-2963(94)90042-6

[63] E. Yoon, H. G. Guffey and V. Kijewski, "The Effects of Information and Company Reputation on Intentions to Buy A Business Service," Journal of Business Research, Vol. 27, No. 3, 1993, pp. 215-228. doi:10.1016/0148-2963(93)90027-M

[64] P. Herbig and J. Milewicz, "The Relationship of Reputation and Credibility to Brand Success," Journal of Consumer Marketing, Vol. 10, No. 3, 1993, pp. 18-24. doi:10.1108/EUM0000000002601

[65] Porter, M. "Competitive Advantage: Creating and Sustaining Superior Performance," The Free Press, New York, 1998.

[66] A. Franklin, "Reputation and Product Quality," Rand Journal of Economics, Vol. 15, No. 3, 1984, pp. 89-97.

[67] E. Garbarino and M. S. Johnson, "The Different Roles of Satisfaction, Trust, and Commitment in Customer Relationships," Journal of Marketing, Vol. 63, No. 2, 1999, pp. 70-87. doi: $10.2307 / 1251946$

[68] F. D. Schoorman, R. C. Mayer and J. H. Davis, "An Integrative Model of Organizational Trust: Past, Present, and Future," Academy of Management Review, Vol. 31, No. 3, 2007, pp. 540-558.

[69] I. Geyskens, J. B. Steenkamp and N. Kumar, "Generalizations about Trust in Marketing Channel Relationships Using Meta-Analysis," International Journal of Research in Marketing, Vol. 15, No. 3, 1998, pp. 223-248. doi:10.1016/S0167-8116(98)00002-0

[70] R. M. Morgan and S. D. Hunt, "The Commitment-Trust Theory of Relationship Marketing," Journal of Marketing, Vol. 58, No. 3, 1994, pp. 20-38. doi:10.2307/1252308

[71] S. Ganesan and R. Hess, "Dimension and Levels of Trust: Implications for Commitment to a Relationship," Marketing Letters, Vol. 8, No. 4, 1997, pp. 439-448. doi:10.1023/A:1007955514781

[72] J. B. Rotter, "A new Scale for the Measurement of Interpersonal Trust," Journal of Personality, Vol. 35, No. 4, 1967, pp. 651-665. doi:10.1111/j.1467-6494.1967.tb01454.x

[73] B. Barber, "The Logic and Limits of Trust," Rutgers University Press, New-Brunswick, 1983.

[74] R. Dwyer, P. Schurr and S. Oh, "Developing Buyer-Seller Relationships," Journal of Marketing, Vol. 51, No. 2, 1987, pp. 11-27. doi:10.2307/1251126

[75] J. B. Rotter, "Generalized Expectancies for Interpersonal Trust," American Psychologist, Vol. 26, No. 5, 1971, pp. 443-452. doi:10.1037/h0031464

[76] K. Blomqvist, "The Many Faces of Trust," Scandinavian
Journal of Management, Vol. 13, No. 3, 1997, pp. 271286. doi:10.1016/S0956-5221(97)84644-1

[77] D. H. McKnight, L. L. Cummings and N. L. Chervany, "Initial Trust Formation in New Organizational Relationships," Academy of Management Review, Vol. 23, No. 3, 1998, pp. 473-490.

[78] J. B. Smith and D. W. Barclay, "The Effects of Organizational Differences and Trust on the Effectiveness of Selling Partner Relationships," Journal of Marketing, Vol. 61, No. 1, 1997, pp. 3-21. doi:10.2307/1252186

[79] K. Atuahene-Gima and H. Li, "When Does Trust Matter? Antecedents and Contingent Effects of Supervisee Trust on Performance in Selling New Products in China and the United States," Journal of Marketing, Vol. 66, No. 3, 2002, pp. 61-81. doi:10.1509/jmkg.66.3.61.18501

[80] G. G. Bell, R. J. Oppenheimer and A. Bastien, "Trust Deterioration in an International Buyer-Seller Relationship," Journal of Business Ethics, Vol. 36, No. 1-2, 2002, pp. 65-78. doi:10.1023/A:1014239812469

[81] R. S. Upchurch and S. K. Ruhland, "The Organizational Bases of Ethical Work Climates in Lodging Operations as Perceived by General Managers," Journal of Business Ethics, Vol. 15, No. 10, 1996, pp. 1083-1093. doi:10.1007/BF00412049

[82] A. Chaudhuri and M. B. Holbrook, "The Chain of Effects from Brand Trust and Brand Affect to Brand Performance: The Role of Brand Loyalty," Journal of Marketing, 65, No. 2, 2001, pp. 81-93. doi:10.1509/jmkg.65.2.81.18255

[83] P. Gurviez and M. Korchia, "Proposition d'une Échelle de Mesure Multidimensionnelle de la Confiance dans la Marque," Recherche et Applications en Marketing, Vol. 17, No. 3, 2002, pp. 41-61. doi:10.1177/076737010201700304

[84] C. Flavian, M. Guinaliu and E. Torres, "The Influence of Corporate Image on Customer Trust, a Comparative Analysis in Traditional versus Internet Banking," Internet Research, Vol. 15, No. 4, 2005, pp. 447-470. doi:10.1108/10662240510615191

[85] J. Singh and D. Sirdeshmukh, "Agency and Trust Mechanisms in Consumer Satisfaction and Loyalty Judgments," Journal of the Academy of Marketing Science, Vol. 28, No. 1, 2000, pp. 150-167. doi:10.1177/0092070300281014

[86] R. Bennett and H. Gabriel, "Reputation, Trust and Supplier Commitment: The Case of Shipping Company/ Seaport Relations," The Journal of Business and Industrial Marketing, Vol. 16, No. 6-7, 2001, pp. 424-438. doi:10.1108/EUM0000000006018

[87] M. Michaelis, D. M. Woisetschläger, C. Backhaus and D. Ahlert, "The Effects of Country Origin and Corporate Reputation on Initial Trust," International Marketing Review, Vol. 25, No. 4, 2008, pp. 404-422. doi: $10.1108 / 02651330810887468$

[88] I. Ajzen and M. Fishbein, "Understanding Attitudes and Predicting Social Behaviour," Prentice-Hall, Englewood Cliffs, 1980.

[89] R. E. Smith and W. R. Swinyard, "Attitude Behavior 
Consistency: The Impact of Product Trial versus Advertising," Journal of Marketing Research, Vol. 20, No. 3, 1983, pp. 257-267. doi:10.2307/3151829

[90] J. R. W. Jacoby and R. Chesnut, "Brand Loyalty Measurement and Management," Wiley, New York, 1978.

[91] J. R. W. Jacoby and D. B. Kyner, "Brand Loyalty versus Repeat Purchasing Behaviour," Journal of Marketing Research, Vol. 10, No. 1, 1973, pp. 1-9. doi: $10.2307 / 3149402$

[92] M. Laaksonen, "Retail Patronage Dynamics: Learning about Daily Shopping Behavior in Contexts of Changing Retail Structures," Journal of Business Research, Vol. 28, No. 1-2, 1993, pp. 3-174. doi:10.1016/0148-2963(93)90024-J

[93] J. Sheth and W. Park, "A Theory of Multidimensional Brand Loyalty," Proceedings, Association for Consumer Research, Chicago, 7-10 November 1974, pp. 449-459.

[94] J. Newman and R. Werbel, "Multivariate Analysis of Brand Loyalty for Major Household Appliances," Journal of Marketing Research, Vol. 10, No. 4, 1973, pp. 404409. doi: $10.2307 / 3149388$

[95] A. G. Woodside, A. Sharma and W. Bearden, "A Dollar Metric Approach for Estimating Consumer Brand Loyalty," Proceedings, American Marketing Association, 1980, pp. 73-85.

[96] D. Ball, P. S. Coelho and A. Machas, "The Role of Communication and Trust in Explaining Customer Loyalty: An Extension to the ECSI Model," European Journal of Marketing, Vol. 38, No. 5-6, 2004, pp. 687-707.

[97] R. L. Oliver, "Whence Customer Loyalty?" Journal of Marketing, Vol. 63, Special Issue, 1999, pp. 33-44. doi: $10.2307 / 1252099$

[98] N. Bontis, L. D. Booker and A. Serenko, "The Mediating Effect of Organizational Reputation on Customer Loyalty and Service Recommendation in the Banking Industry," Management Decision, Vol. 45, No. 9, 2007, pp. 14261445. doi:10.1108/00251740710828681

[99] J. A. M. Garcia and L. M. Caro, "Building Better Causal Models to Measure the Relationship between Attitudes and Customer Loyalty," International Journal of Market Research, Vol. 50, No. 4, 2008, pp. 437-449.

[100] J. Bergeron, L. Ricard and J. Perrien, "Les Déterminants de la Fidélité des Consommateurs Commerciaux dans l'Industrie Bancaire Canadienne," Canadian Journal of Administrative Sciences/Revue Canadienne de l'Administration, Vol. 20, No. 2, 2003, pp. 107-120. doi:10.1111/j.1936-4490.2003.tb00697.x

[101] N. Eakuru and N. K. N. Mat, "The Application of Structural Equation Modeling (SEM) in Determining the Antecedents of Customer Loyalty in Banks in South Thailand," The Business Review, Vol. 10, No. 2, 2008, pp. 129-139.

[102] B. Jin, J. Y. Park and J. Kim, "Cross-Cultural Examination of the Relationships among Firm Reputation, e-Satisfaction, e-Trust, and e-Loyalty," International Marketing Review, Vol. 25, No. 3, 2008, pp. 324-337. doi: $10.1108 / 02651330810877243$
[103] D. Ribbink, A. C. R. van Riel, V. Liljander and S. Streukens,. "Comfort Your Online Customer: Quality, Trust and Loyalty on the Internet," Managing Service Quality, Vol. 14, No. 6, 2004, pp. 446-456. doi:10.1108/09604520410569784

[104] C. Flavian, E. Torres and M. Guinaliu, "Corporate Image Measurement: A Further Problem for Tangibilization of Internet Banking Services," The International Journal of Bank Marketing, Vol. 22, No. 4/5, 2004, pp. 366-384. doi: $10.1108 / 02652320410549665$

[105] C. J. Fombrun, N. A. Gardberg and J. W. Sever, "The Reputation Quotient: A Multi-Stakeholder Measure of Corporate Reputation," The Journal of Brand Management, Vol. 7, No. 4, 2000, pp. 241-255.

[106] G. Walsh and S. E. Beatty, "Customer-Based Corporate Reputation of a Service Firm: Scale Development and Validation," Journal of the Academy of Marketing Science, Vol. 35, No. 1, 2007, pp. 127-143. doi:10.1007/s11747-007-0015-7

[107] S. A. Taylor, "Assessing Regression-Based Importance Weights for Quality Perceptions and Satisfaction Judgments in the Presence of Higher Order and/or Interaction," Journal of Retailing, Vol. 73, No. 1, 1997, pp. 135159. doi:10.1016/S0022-4359(97)90018-X

[108] V. A. Zeithaml, L. L. Berry and A. Parasuraman, "The Behavioral Consequences of Service Quality," Journal of Marketing, Vol. 60, No. 2, 1996, pp. 31-46. doi: $10.2307 / 1251929$

[109] B. M. Byrne, "Structural Equation Modelling with AMOS, Basic Concepts, Applications and Programming," Lawrence Erlbaum Associates, Mahwah, 2001.

[110]C. Fornell and D. F. Larcker, "Evaluating Structural Equaion Models with Unobservable Variables and Measurement Error," Journal of Marketing Research, Vol. 18, No. 1, 1981, pp. 39-50. doi:10.2307/3151312

[111] E. Naumann, “Ten Easy Ways to Lose Your Customer's Trust," Business Horizons, Vol. 35, No. 5, 1992, pp. 3034. doi:10.1016/0007-6813(92)90050-J

[112] M. Omar, R. LWilliams, Jr and D. Lingelbach, "Global Brand Market-Entry Strategy to Manage Corporate Reputation," The Journal of Product and Brand Management, Vol. 18, No. 3, 2009, pp. 177-187. doi:10.1108/10610420910957807

[113] Y. Xie and S. Peng, "How to Repair Customer Trust after Negative Publicity: The Roles of Competence, Integrity, Benevolence and Forgiveness," Psychology and Marketing, Vol. 26, No. 7, 2009, pp. 572-584. doi:10.1002/mar.20289

[114] D. W. Barclay and J. B. Smith, "The Effects of Organizational Differences and Trust on the Effectiveness of Selling Partner Relationship," Journal of Marketing, Vol. 61, No. 1, 1997, pp. 3-31. doi:10.2307/1252186

[115] R. A. Peterson and R. W. Wilson, "Measuring Customer Satisfaction: Fact and Artifact," Journal of the Academy of Marketing Science, Vol. 20, No. 1, 1992, pp. 61-71. doi:10.1007/BF02723476 


\section{Appendix A}

\section{Measures of Corporate Identity, Corporate Image, Corporate Reputation, Customer Trust and Customer Loyalty}

\section{Corporate identity}

- As a cooperative organization, my credit union is there to help its members.

- My credit union is different from a bank.

- I like my credit union's logo. Corporate image

- I have always had a good impression of my credit union.

- I believe that the image of my credit union is better than its competitors.

- When I hear about financial services, the name of my credit union comes to my mind first.

\section{Corporate reputation}

- My credit union always fulfills the promises that it makes to its customers.
- I believe that the reputation of my credit union is better than its competitors.

- I believe that my credit union is fair in its decisions and actions.

\section{Customer trust}

- I believe that integrity is a well-respected principle in my credit union.

- The expertise in financial services of my credit union is well known.

- My credit union is always concerned about its members' well-being.

- My credit union is more concerned about its members' well-being than its financial performance.

Customer loyalty

- For financial services, my credit union remains my first choice.

- I will continue to do business with my credit union.

- I would encourage friends and relatives to do business with my credit union. 